\title{
Device for Applying a Thin Layer of Oil onto the Inner Surface of Steel Pipes
}

Jozef Svetlík ${ }^{1}$, Ján Král’1, Tomáš Brestovič ${ }^{1}$, Martin Pituk ${ }^{2}$

${ }^{1}$ Faculty of Mechanical Engineering, Technical University in Košice, Letná 9, 04200 Košice, Slovakia, E-mail: jozef.svetlik@tuke.sk

${ }^{2}$ B/S/H/ Drives and Pumps s.r.o., Továrenská 2, 07101 Michalovce, Slovakia, E-mail: martin.pituk@bshg.com

The technological solution relates to the device for applying a layer of oil film to the inner surface of pipes of different cross section. It is suitable for metallurgical and engineering applications where it is required to use an oil film - a thin coating on the inner surface of pipes of different cross section and different lengths, due to: corrosion protection, disinfection, reducing the surface friction of the inner surface, or for other reasons. The formulation of this concept is applicable to a broad portfolio of pipe types of different sizes, cross-sections shapes and lengths. The technical solution falls within engineering and metallurgy fields.

Keywords: corrosion protection, tubes, pipes, oil film layer

\section{Acknowledgement}

This contribution has been supported by research grants: VEGA 1/0124/15 "Research and development of advanced methods for virtual prototyping of manufacturing machines" and APVV-15-0149 "Research of new measuring methods of machine condition".

\section{References}

[1] VALDEZ, B., SCHORR, M., BASTIDAS, JM. (2015). The natural gas industry: equipment, materials, and corrosion. In: Corrosiom reviews, Vol. 3, No. 33, pp. 175 - 185. Freund Publishing House Ltd.

[2] TAN, YJ. (2013). An overview of techniques for characterizing inhomogeneities in organic surface films and uderfilm localized corrosion. In: Progress in organic coatings, Vol. 76, No. 5, pp. 791 - 803. Elsevier Science SA. Switzerland.

[3] HASSAN, MM., BARKER, H., COLLIE, S. (2015). Enhanced corrosion inhibition of mild steel by cross-linked lanolin-coatings. In: Progress in organic coatings, Vol. 78, pp. 249 - 255. Elsevier Science SA. Switzerland.

[4] SUN, C., SUN, JB., WANG, Y., WANG, SJ., LIU, JZ. (2014). Corrosion mechanism of OCTG carbon steel in supercritical CO2/Oil/Water. In: Systematica metallurgica sinica, Vol. 50, No. 7, pp. 811 - 820. Science Press, China.

[5] KOLLÁTH, L., KUREKOVÁ, E., PLOSKUŇÁKOVÁ, L., BENIAK, J. (2009). Non-conventional produc-tion machines. In: Scientific Proceedings 2009, pp. 69 - 75. Faculty of Mechanical Engineering, Slovak University of Technology in Bratislava, Slovakia.

[6] VOTAVA, J., KUMBAR, V. (2017). Usage of waterborne acrylate anticorrosion systems for ecological en-vironment. In: Manufacturing Technology. Vol. 17, pp. 103 - 110. Czech Republic.

[7] TADEUSZ E. ZABOROWSKI ... [et al.]. (2015). Analysed of machined surfaces, pp. 125. Institute of Sci-entific Research and Expertise in Gorzów Wlkp. Poland.

[8] PRISLUPČÁK, M., PANDA, A. (2016) Comparsion and Analysis of the Flow Rate, In: Engineering Materials. Vol. 663, pp. 197 - 204. Slovakia.

[9] MAKSIMOV, E. A., KREHEL, R., POLLÁK, M. (2016). Prospective systems and technologies for the treatment of wastewater containing oil substances. In: Clean Technologies and Environmental Policy. No. 1, pp. 161 - 170. Springer Verlag, Germany.

[10] BARON, P.... [Et al.]. (2015). Research and Correlation of Diagnostic Methods for Assessment of the State of Oil Filling in Cycloid Gearbox, In: Advances in Materials Science and Engineering, pp. 97841 - 97841. Hindawi Publishing Corporation, USA.

[11] DOBRÁNSKY, J., BARON, P., VOJNOVÁ, E., MANDULÁK, D. (2016). Optimization of the production and logistics processes based on computer simulation tools, In: Key Engineering Materials, Vol. 669, No. 3, pp. 532 540. Trans Tech Publications. Switzerland. 
[12] KORBA, P., PIL'A, J., SABO, J., ANTOŠKO, M. (2014). The use of CAX systems as a tool to reduce the economic costs in the aviation industry. In: SGEM 2014, pp. 385 - 392. Technical University of Košice, Slovakia.

[13] ŽILINSKÝ, A., SVETLÍK, J., DRABIKOVÁ, E. (2014). New CAD softwares in engineering. In: Transfer of inovations, pp. 137 - 140. Technical University of Košice, Slovakia.

[14] RADZEVICH, S. P., KREHEL', R. (2011). Application priority mathematical model of operating parame-ters in advanced manufacturing technology. In: The International Journal of Advanced Manufacturing Technology, Vol. 56, No. 2, pp. 835 - 840. Springer London, United Kingdom.

[15] DOBRÁNSKY, J., BARON, P., KOČIŠKO, M., TELIŠKOVÁ, M. (2015). Monitoring diagnostic indicators during operation of a print machine, In: Advances in Science and Technology, Vol. 9, No. 28, pp. 34 - 39. Soc Polish Mechanical Engineers \& Technicians. Poland.

[16] JENČURÁKOVÁ, D., PALENČÁR, R. (2016). Optimizing Management of the Measurement System of the Technological Process. In: Manufacturing Technology. Vol. 16, pp. 107 - 113. Czech Republic.

[17] KYNCL, J. (2016). Digital Factory Simulation Tools. In: Manufacturing Technology. Vol. 16, No.2, pp. 371 375. Czech Republic. 